\title{
POŻYTKI Z MIEJSCA NA KARCIE WYBORCZEJ W KONKURENCYJNYCH WYBORACH BEZPOŚREDNICH ORGANU WYKONAWCZEGO GMIN ROZGRYWANYCH W TRYBIE OPEN RACE*
}

\author{
ADVANTAGES OF THE POSITION ON THE BALLOT CARD IN \\ OPEN RACE COMPETITIVE DIRECT ELECTIONS \\ TO COMMUNAL EXECUTIVE AUTHORITIES
}

Sławomir Bartnicki*

\begin{abstract}
ABSTRAKT
$-$

Spodziewane wprowadzenie ograniczenia kadencyjności dla przedstawicieli gminnej egzekutywy w kształcie dotychczas nieujawnionym skutkować będzie gwałtownym wzrostem liczby wyborów rozgrywanych $\mathrm{w}$ trybie open race, czyli takich, w których uprzednio rządzący nie kandyduje. W takiej sytuacji na szanse sukcesu wyborczego może wpływać miejsce kandydata na karcie wyborczej, co w tych wyborach przy aktualnie obowiązującej ordynacji zależy od kolejności alfabetycznej. Toteż głównym celem przedkładanego artykułu jest określenie wpływu na poparcie wyborcze w I turze oraz na szanse zwycięstwa wynikające $\mathrm{z}$ umiejscowienia kandydata na liście do głosowania w dotychczasowych wyborach organu wykonawczego gmin w 2006,
\end{abstract}

The anticipated introduction of limitation to terms of office of communal executive representatives, though yet not known in detail, is going to result in rapid growth of open race elections: elections in which the individuals currently holding the positions do not run. In this situation, the candidate's position on the ballot card, which currently depends on the alphabetic order, may influence their chances of victory. Thus, the main goal of the article is to determine how the candidate's position on the ballot card affected their electoral support in the first ballot and the chance of victory in the previous elections for communal executive authorities in 2006, 2010, and 2014, when incumbents did not run. Conclusions drawn so far in international literature

* Artykuł powstał na podstawie badań przeprowadzonych do projektu finansowanego przez Narodowe Centrum Nauki, Sonata 7 (numer projektu: 2014/13/D/HS5/02010), pt.: „Uwarunkowania reelekcji egzekutywy gminnej po 2002 roku w Polsce".

* Uniwersytet w Białymstoku, Wydział Historyczno-Socjologiczny. 
2010 i w 2014 roku, w których poprzednio rządzący nie kandydował. Dotychczasowe wnioski w tym zakresie płynące $z$ literatury światowej wskazują, że pierwsze i ostatnie miejsce na liście do głosowania zwiększa poparcie wyborcze również w wyborach rozgrywanych w obecności inkumbenta, a jego oddziaływanie powinno być jeszcze większe w sytuacji wyborów typu open race. Wyniki analizy ujawniają, że pozycja na karcie wyborczej ma wpływ na poparcie w I turze w tego typu wyborach. Umiejscowienie na liście do głosowania moderuje również prawdopodobieństwo kandydowania w kolejnych wyborach i nie wynika to ze zwiększonego poparcia $\mathrm{w}$ wyborach poprzednich. Oprócz pozycji na karcie wyborczej $\mathrm{w}$ analizie brano też pod uwagę wpływ zmiennych kontrolnych, takich jak: płeć, afiliacja komitetu wyborczego, wykształcenie, wiek, kandydowanie w wyborach poprzednich, ludność gminy i liczba kontrkandydatów w wyborach. Wnioski skłaniają do dyskusji nad możliwością rezygnacji z rozmieszczania kandydatów na karcie wyborczej w tego typu wyborach wg kolejności alfabetycznej.

Słowa kluczowe: miejsce na karcie wyborczej, wybory bez obecności inkumbenta (open race), egzekutywa gminna show that the first and last position on the ballot card enhance electoral support even in elections with the participation of incumbents, and their influence should be even stronger in the case of open race elections. The results of the analysis reveal that in such elections the position on the ballot card has an impact on support in the first ballot. The candidate's position also moderates the probability of running in the next election, which is not the effect of greater support in the previous election. Apart from the position on the ballot card, the analysis also involved the influence of control variables such as sex, affiliation of the election committee, education, age, running in the previous election, commune population, and the number of rivals. The conclusions are an inspiration for discussion on possible departure from the application of the alphabetic order on the ballot card in this type of election.

Keywords: position on the ballot card, election without the participation of the incumbent (open race), communal executive

\section{WPROWADZENIE}

Wiele dotychczasowych analiz poparcia wyborczego wypracowało wnioski w zakresie przewag ubiegających się o stanowiska $\mathrm{z}$ wyboru, przewag, które możemy określać jako strukturalne. Należy przez to rozumieć zwiększenie szans kandydującej osoby w sposób do końca niezależny ani od kandydata, ani od cech okręgu wyborczego (gminy w bieżącej analizie). Najlepiej udokumentowaną przewagą tego typu jest status inkumbenta, czyli ubieganie się o reelekcję uprzednio rządzącego. Status inkumbenta jest najsilniejszym czynnikiem zwycięstwa wyborczego (Oliver, Ha, Callen, 2012). Jego przemożny wpływ odnotowuje się tak w wyborach centralnych (Gelman, King, 1990; Stonecash, 2008), jak i w wyborach lokalnych (np.: Freier, 2015; Trounstine, 2011) w wielu miejscach 
świata. Cecha ta traci moc sprawczą jedynie w warunkach ekstremalnie silnej delegitymizacji władzy na płaszczyźnie ekonomicznej (Mcdonald, 2014) i takie zjawisko (incumbency dis-advantage) jest relatywnie rzadko odnotowywane, np. w Brazylii (Titiunik, 2011), w Indiach (Uppal, 2009) czy w Zambii (Mcdonald, 2014).

Innego typu przewagą strukturalną, której poświęcono bieżącą analizę, jest pozycja zajmowana przez kandydata na karcie wyborczej (tzw. Ballot Position). Wnioski w tym zakresie wypracowywane w ostatnich latach są coraz bardziej jednoznaczne i wskazują, że miejsce, które zajmuje kandydat na karcie do głosowania, może efektywnie moderować poparcie wyborcze. Ogólnie wskazuje się tu, że umieszczenie na początku i na końcu listy ma najbardziej pomagać kandydatowi (King, Leigh, 2009). Z drugiej strony wielkość i obecność tego efektu może zależeć od specyfiki listy wyborczej: liczba kandydatów, oznaczenia kandydatów różnymi cechami, np. komitet wyborczy (partyjny/bezpartyjny), zawód, wiek, tytuł akademicki itp., oraz od specyfiki głosowania: czy z listy wybiera się jednego kandydata czy kilku, czy stopniuje się poparcie, czy mamy do czynienia z głosem negatywnym wreszcie od tego, czy na karcie do głosowania nazwiska rozmieszczone są w jednej czy w wielu kolumnach itp. Podejść może być tu wiele w zależności od kraju i typu wyborów. Istotna jest przy tym wszystkim obserwacja odnotowywana w wielu badaniach, która wskazuje na oddawanie głosu sugerując się pozycją kandydata na liście wyborczej. Dzieje się tak w sytuacji, kiedy głosujący dysponuje jedynie minimalnym zakresem informacji o kandydatach lub w ogóle nie posiada o nich informacji, a mając przed sobą kartę do głosowania, musi na kogoś wskazać. W takich okolicznościach głosujący ma zazwyczaj premiować pierwszych i ostatnich na liście. Jest to bodaj najlepiej udokumentowany wniosek wynikający z badań nad problematyką rozmieszczenia kandydatów na listach wyborczych. Ogólnie brak wskazówek decyzyjnych dla wyborcy, jak: status inkumbenta, przynależność partyjna, osobista znajomość kandydata albo znajomość kandydującego jedynie z mediów czy też sytuacja, kiedy wyborca nie interesuje się danymi wyborami i nie ma o nich wiedzy, a mimo to w głosowaniu uczestniczy - wszystko to stanowi dla wyborcy dysonans poznawczy, którego niwelacja prowadzi do premiowania kandydatów pozycjonowanych na początku i/lub na końcu listy¹.

1 W Australii przy głosowaniu preferencyjnym, gdzie wyborca oznacza kandydatów na karcie do głosowania wg skali swojej preferencji, a nie wskazuje jednego kandydata spośród ogółu dostępnych, zaobserwowano, że wyższa pozycja kandydata na liście oznacza więcej wyższych ocen wybor- 


\section{KORZYŚCI DLA KANDYDATA Z MIEJSCA NA KARCIE WYBORCZEJ}

Pogląd, że pozycja na liście wyborczej ma wpływ na szanse zwycięstwa, ma być tak wiekowy jak usystematyzowany namysł nad życiem politycznym (Blom-Hansen, Elklit, Serritzlew, Villadsen, 2014). Choć wcześniejsze badania w tym zakresie krytykowano pod względem stosowanej metodologii (np. Darcy, McAllister, 1990). Mmiały one raczej koncentrować się na wykazywaniu przewag i strat wśród kandydatów znajdujących się na różnych pozycjach listy, a nie umiejscawianych brzegowo, poza tym pomijały intencjonalność lokowania kandydatów na listach (Blom-Hansen $\mathrm{i}$ in.).

Dominujące obecnie stanowisko zakładające, że im mniej informacji posiada wyborca o kandydatach, tym większą rolę we wskazaniu kandydata odgrywać będzie jego pozycja na karcie wyborczej (np.: Miller, Krosnick, 1998). David Brockington, (Brockington, 2003), sugeruje, że w podjęciu decyzji wyborczej rolę odgrywają trzy stopniowane „poziomy informacji”, którymi posługuje się wyborca. Pierwszy stanowią informacje zgromadzone o kandydatach przez wyborcę. Ten zakres tworzy też oddziaływanie statusu inkumbenta, wcześniejsze doświadczenia polityczne, w tym kandydowanie np. w wyborach parlamentarnych (Marcinkiewicz, Stegmaier, 2015), a co za tym idzie, ekspozycja kandydata w mediach tradycyjnych i elektronicznych (Spierings, Jacobs, 2014). Wcześniejsze doświadczenia polityczne kandydującego w różnych formach i zakresach, wspierane przez ekspozycję medialną, są w stanie spowodować, że dany kandydat będzie przez wyborcę rozpoznawalny.

Jeżeli powyżej scharakteryzowany sposób podejmowania decyzji wyborczej nie zostanie wdrożony, czyli w sytuacji, kiedy głosujący nie dysponuje informacjami o kandydatach i ich nie rozpoznaje, wówczas wyborca będzie się kierować uproszczeniami decyzyjnymi bazującymi na stereotypach. Tutaj rolę odgrywają informacje zawarte na karcie do głosowania, które pomagają w charakterystyce kandydata, a wybór zależy od osobistej identyfikacji wyborcy z wybieranym pod względem podobieństwa czy też kierowania się stereotypami w zakresie takich cech kandydata, jak: płeć, wiek, brzmienie nazwiska czy rasa (Brockington, 2003). Być może to powoduje, że wzrost liczby kobiet na czołowych miejscach na listach wyborczych do polskiego Sejmu nie przekłada się na wzrost poparcia

ców. Zjawisko to doczekało się tam formalnej nazwy „oślego głosowania” (donkey voting, zob. King, Leigh, 2009). 
dla kandydatek i w konsekwencji na zwiększenie udziału wybieranych kobiet (Marcinkiewicz, Stegmaier, 2015).

Wreszcie, jeżeli informacje drugorzędne okażą się niewystarczające dla podjęcia decyzji, wówczas wyborca ma sugerować się pozycją zajmowaną na karcie wyborczej. Dokonywanie wyboru na podstawie informacji trzeciorzędnych może być dyktowane m.in. tzw. efektem pierwszeństwa, który jest mechanizmem psychologicznym i sugeruje, że spośród zbioru opcji do wyboru wybierane są zwykle pierwsze dostępne (Miller, Krosnick, 1998). Ludzi ma charakteryzować tendencja do systematycznego przewartościowywania obiektów umieszczanych na początku listy. Tendencja ta ma się manifestować w metaforach językowych oraz w mimowolnym kojarzeniu tego, co dobre, $\mathrm{z}$ tym co na górze, a tego, co złe, z tym, co na dole (Kim, Krosnick, Casasanto, 2015). Badanie eksperymentalne w zakresie poparcia dwóch fikcyjnych kandydatów, w wielu następujących po sobie wyborach, w których wybierani występowali w różnej kolejności, wykazało wzmocnienie efektu pierwszeństwa, m.in. wtedy, kiedy wybierający: dysponowali mniejszym zakresem informacji o kandydatach; mieli mniejsze umiejętności poznawcze; nie przywiązywali większej wagi do swoich wyborów; i włożyli mniej wysiłku w poznanie kandydata. Stwierdzono też, że horyzontalna prezentacja nazwisk u osób leworęcznych zwiększa efekt oddziaływania pozycji na liście (Kim i in., 2015). Pozycja na liście ma również silniej oddziaływać w sytuacji wyborów, w których nie kandyduje inkumbent (Miller, Krosnick, 1998), na czym koncentruję się w bieżącej analizie. Brak najsilniej ogniskującego uwagę wyborców sygnału powinien zwiększać oddziaływanie pozycji na liście wyborczej, chociaż w przypadku tych wyborów istotną rolę mediującą może odgrywać instytucja namaszczenia następcy przez ustępującego.

Najwięcej badań eksperymentalnych i prowadzonych na danych wyborczych, a dotyczących problematyki przewag wynikających z pozycjonowania na liście, pochodzi z USA. Tam też zwykle ujawnia się istotne oddziaływanie takich uwarunkowań (np.: Miller, Krosnick, 1998; Meredith, Salant, 2013; Chen, Simonovits, Krosnick, Pasek, 2014; a w zakresie eksperymentu: Kim i in., 2015) choć możemy doszukać się wyników badań, w których takiego oddziaływania nie zaobserwowano (np.: Alvarez, Sinclair, Hasen, 2006). Poza USA wykryto pozytywny wpływ bycia pierwszym i ostatnim na listach wyborczych, m.in. w wyborach do polskiego Sejmu w 2007 (Marcinkiewicz, 2014) oraz w wyborach do Sejmu RP w 2011 roku i w wyborach do Izby Deputowanych w 2010 roku w Republice Czeskiej (Marcinkiewicz, Stegmaier, 2015). 


\section{WYBORY ORGANU WYKONAWCZEGO GMIN W POLSCE}

Od 2002 roku wybory organu wykonawczego gmin w Polsce prowadzone są w trybie wyborów bezpośrednich. Wcześniej wyboru osoby na to stanowisko dokonywała rada gminy, jednak do rezygnacji z tej formuły wyłaniania lokalnych włodarzy przyczyniły się m.in. konflikty w radach gmin powstające na tym tle (Regulski, 2000), oraz chęć podniesienia zaangażowania lokalnych społeczności w gminne życie polityczne (Magnier, 2006). Wprowadzeniu ustawy o bezpośrednim wyborze wójta towarzyszyły również głosy krytyczne sugerujące przewartościowanie roli gminnych włodarzy głównie w zakresie ich funkcji władczych względem rad gminnych (Janik, 2007). Jak też sugerował jeszcze w 2004 roku Andrzej Piasecki, wprowadzenie bezpośredniego wybierania wójtów doprowadziło obecnie do dominacji trybu większościowego w elekcjach rad gminnych, (Piasecki, 2004).

Ostatecznie wprowadzenie bezpośredniego wybierania wójtów ujawniło występowanie obserwowanych gdzie indziej i typowych dla tego typu wyborów zjawisk. Należy tu wymienić dominację inkumbentów moderowaną przede wszystkim wielkością ludnościową gmin. W pierwszych wyborach bezpośrednich do tych stanowisk w 2002 roku zwyciężyło 60\% inkumbentów rządzących przed tą elekcją, w kolejnych trzech do tej pory przeprowadzonych wyborach dominacja inkumbentów była już wyższa, w 2010 najwięcej inkumbentów uzyskało reelekcję jak do tej pory, a wybory w 2014 roku dla ubiegających się o reelekcję okazały się najmniej łaskawe. Najniższa rotacja uprzednio rządzących na tych stanowiskach występuje w największych ośrodkach, podobnie jak np. w Kanadzie (Kushner, Siegel, Stanwick, 1997), następnie w najmniej ludnych gminach, co jest pochodną relatywnie najniższej podaży kandydatów w gminach z niższą liczbą ludności. Jednocześnie nie obserwujemy efektu umacniania się inkumbentów z wyborów na wybory, co nie dotyczy ośrodków z liczbą ludności przekraczającą 100 tys., mimo że tam konkurencja jest największa, a kontrola społeczna powinna być tam najsilniejsza i najbardziej wydajna.

Jak do tej pory czterokrotnie rozegrano wybory w trybie bezpośrednim, w których wybierano wójtów, burmistrzów i prezydentów miast. We wszystkich tych wyborach pozycja kandydujących na liście wyznaczana jest wg kolejności alfabetycznej, od nazwiska kandydata. Na karcie do głosowania oprócz nazwiska i imienia/imion osoby kandydującej umieszcza się również nazwę komitetu wyborczego. Inne cechy kandydatów nie są zamieszczane na karcie do głosowania. W przypadku komitetu wyborczego partii politycznej głosujący może 
ten fakt łatwo zidentyfikować. W każdych tego typu wyborach od 2002 roku obowiązuje też jednakowa ordynacja większościowa. Aby głos był ważny, głosujący musi postawić znak X w komórce obok nazwiska wybieranego przez siebie kandydata. Postawienie więcej niż jednego znaku X albo brak takiego oznaczenia powoduje, że głos jest nieważny. Wygrywa ten kandydat, który dostanie najwięcej głosów w gminie. W przypadku jednego tylko kandydata w wyborach musi on przekroczyć próg 50\% ważnych oddanych na siebie głosów, aby zostać wybranym. Mamy tu zatem do czynienia z prostym trybem głosowania. O kolejności na liście decyduje porządek alfabetyczny, kandydaci są dodatkowo oznaczani jedynie przez przypisanie im nazwy ich komitetu wyborczego, a głosujący wskazuje tylko jednego preferowanego przez siebie kandydata. Taki schemat analizowanych wyborów powinien umożliwiać względnie prostą weryfikację wpływu pozycji na liście wyborczej na szanse wyboru i poparcia wyborczego, szczególnie w wyborach, w których inkumbent nie kandyduje (wybory w tzw. trybie open race).

\section{DANE}

Kluczową zmienną analizy jest pozycja na liście do głosowania zajmowana przez kandydata, a wyznaczana wg porządku alfabetycznego od nazwiska. W tym badaniu pozycje na liście wyznaczono wg kolejności alfabetycznej od nazwiska kandydata. Taka kolejność jest na ogół zgodna z pozycją na liście danego kandydata, sugerowaną przez PKW. Niekiedy pojawiają się rozbieżności w pozycji wyznaczanej alfabetycznie i przez PKW. Dotyczy to np. w 2006 roku Krzeszowic, gdzie brakuje kandydata na pozycji 3, a kandydat na ostatniej pozycji (miejscu) w tych wyborach w tej gminie oznaczony jest cyfrą 6 , co daje w sumie 5 kandydatów w tej gminie, a nie sześciu. W tych samych wyborach w mieście Iława mamy w sumie 3 kandydujących oznaczonych pozycjami: 2, 3 i 4. W Łodzi na 12 pozycji brakuje ósmego kandydata, co daje w sumie 11 kandydujących w 2010 roku, a nie 12. Z kolei w wyborach w 2006 roku, w gminie Jedwabne kandydowały 4 osoby, ale przypisano do nich pozycje: 2, 3, 4 i 5. We wszystkich tych przypadkach ujednolicono pozycje na liście wg liczby kandydujących i kolejności alfabetycznej, co na przykładzie Jedwabnego oznacza: 1, 2, 3 i 4.

Baza danych stosowana w analizie zawiera informacje o wszystkich zakwalifikowanych startach wyborczych w dotychczasowych wyborach bezpośrednich do gminnej egzekutywy $(\mathrm{N}=33680)$. Z bazy wyłączono starty wyborcze w tych 
gminach, gdzie w jakichkolwiek dotychczasowych wyborach bezpośrednich wybory rozgrywano w III turze albo gdzie gminnego włodarza wybierała rada gminy. Wykluczono także starty wyborcze we wszystkich dotychczasowych wyborach bezpośrednich w obydwu gminach Zielona Góra oraz w gminie Jaśliska. W tych pierwszych w 2014 roku wyborów samorządowych nie organizowano z powodu ich scalenia, a gmina Jaśliska na mapie administracyjnej funkcjonuje dopiero od 2010 roku jako jednostka wydzielona $\mathrm{z}$ obszaru gminy Dukla. Obserwacje, czyli starty wyborcze, opisano wielozakresowym zestawem cech charakteryzujących kandydatów i okręgi wyborcze (gminy). Umożliwia to m.in. prowadzenie bieżącej analizy, która poszukuje zależności między pozycją na liście wyborczej a poparciem wyborczym. Następnie dla potrzeb bieżącej analizy $\mathrm{z}$ wyjściowej bazy $(\mathrm{N}=33680)$ wybrano starty wyborcze rozgrywane bez obecności inkumbenta, w których kandydowały co najmniej dwie osoby. W wyborach w 2006, 2010 i w 2014 roku takich startów było w sumie N=2925. Pod uwagę brane są jedynie wybory open race od 2006 roku, bo wybory w 2002 roku służą do określenia statusu inkumbenta.

\section{METODOLOGIA}

Weryfikowanie wpływu miejsca na karcie wyborczej na wielkość poparcia i szanse wyboru odbywa się przy zastosowaniu modeli regresji. Zasadnicze zmienne dla analizy, czyli pierwsza i ostatnia pozycja na liście wyborczej, oznaczane są jako zmienne binarne. Jeżeli dany kandydat zajmuje pierwszą pozycję, wówczas do modelu wprowadzana jest wartość 1; jeżeli jego pozycja jest inna, wówczas wprowadzana wartość to 0 . Analogicznie dla ostatniej pozycji na liście wyborczej. W operacjonalizacji tych zmiennych nie stosowano, jak w wyborach parlamentarnych, podejścia polegającego na standaryzacji procentowej (zob. np. Marcinkiewicz, 2014; Faas, Schoen, 2006). W analizowanych wyborach liczba kandydatów jest znikoma w porównaniu na przykład do wyborów parlamentarnych w Polsce, toteż liczba pozycji na liście wyborczej jest tu relatywnie niewielka. W dotychczasowych wyborach włodarzy gminnych w Polsce od 2006 roku, w których nie kandydował inkumbent o stanowisko gminnego włodarza, przeciętnie ubiegało się 4,64 kandydatów; a w wyborach w obecności uprzednio rządzącego ta wartość wynosi 3,98. W wyborach open race obserwujemy zatem wzrost konkurencji, podobnie jak i w innych krajach w wyborach lokalnych, w których inkumbent nie kandyduje 
(np. Hajnal, Lewis, Louch, 2002). Liczba kandydatów w tych wyborach stanowi zasadniczą różnicę w stosunku do wyborów parlamentarnych w Polsce analizowanych przez Marcinkiewicza w 2007 (Marcinkiewicz, 2014) i w 2011 (Marcinkiewicz, Stegmaier, 2015), gdzie lista kandydatów liczy kilkadziesiąt nazwisk. Analizie nie podlega tu odsetek głosów w ramach listy w ramach okręgu, tylko odsetek głosów na kandydata w całym okręgu wyborczym, czyli w gminie. Z powyższych powodów wystarczająca powinna być prosta operacjonalizacja zero-jedynkowa zmiennych kluczowych.

Pozostałe zmienne kontrolne, stosowane przy testowaniu oddziaływania zajmowanego miejsca na liście do głosowania na poparcie wyborcze, to: płeć, typ komitetu wyborczego kandydata (bezpartyjny; partyjny); wykształcenie; wiek; kandydowanie bądź nie w przynajmniej jednych wyborach poprzednich od 2002 roku; liczba ludności gminy oraz liczba kandydatów/konkurentów w tych wyborach. W przypadku płci przez 1 oznaczano mężczyzn, a przez 0 kobiety. Wiek zdecydowano się przedstawiać w dekadach, co obniża wartość predykcyjną, ale $\mathrm{z}$ drugiej strony niweluje problem wzajemnych korelacji zmiennych niezależnych. Dlatego kandydat w wieku np. 52 lat w modelu reprezentowany jest przez wartość 5,2. Należy jednocześnie zwrócić uwagę na fakt znacznych rozbieżności w wieku kandydatów w tych wyborach, co wynika ze sposobu pozyskiwania tej zmiennej przez PKW, bo kandydaci samodzielnie określają własny wiek. Skutkuje to przykładowo tym, że w wyborach w 2006 roku dany kandydujący ma np. 50 lat, a w kolejnych wyborach w 2010 roku wiek tej samej osoby wg PKW wynosić może 53 albo 55 lat. Właściwość ta również przemawia za tym, aby wiek do modelu analitycznego wprowadzać w postaci rekodowanej. Kolejną zmienną jest wykształcenie kandydujących. W tym przypadku zdecydowano się na operacjonalizowanie tej zmiennej poprzez $1 \mathrm{w}$ sytuacji, kiedy kandydujący ma wykształcenie wyższe (co obejmuje również wykształcenie niepełne wyższe), oraz przez $0 \mathrm{w}$ sytuacji, kiedy kandydujący nie posiada wykształcenia wyższego. Przez wykształcenie wyższe należy też rozumieć sytuację, kiedy kandydująca osoba legitymuje się tytułem naukowym. Zmienna ta przez PKW raportowana jest w wartościach nieostrych. W przypadku większości kandydatów poziom ich wykształcenia jest określany jako główna wartość bazowa, np. wyższe, średnie, itp. W przypadku niektórych $\mathrm{z}$ kandydatów spotykamy uszczegółowienia, co egzemplifikuje się przykładowo zapisem: wyższe techniczne, wyższe administracyjne, wyższe ekonomiczne, ale możemy też spotkać zapis w postaci: wyższe magisterskie albo pótwyższe (co prawdopodobnie oznacza wykształcenie licencjackie). Dlatego charakterystyka kandydata w tym względzie zawierająca 
słowo „wyższe” skutkuje kodowaniem jako 1 . W praktyce oczywiście włącza to również i tych, którzy legitymują się wykształceniem licencjackim, lub ewentualnie w momencie wyborów formalnie nie ukończyli nawet licencjatu, ale dla PKW swoje wykształcenie określili jako wyższe. Charakteryzowane tu problemy z rzetelnością danych zastanych, jako pochodna ich gromadzenia i archiwizacji, są podobne do tych, które odnotowuje się przy analizach danych z innych źródeł statystyk publicznych (np. Halamska, 2013). Wreszcie oceniając, jak cechy kandydujących wpływają na ich wynik wyborczy, spoglądamy również na formalną afiliację komitetu wyborczego kandydata. Komitety wyborców lub organizacji kodowano jako 1 (komitety bezpartyjne), a komitety partii lub koalicji partii politycznych kodowano jako 0 (komitety partyjne).

Weryfikacji poddano również fakt wcześniejszego kandydowania w wyborach tej samej osoby, w tej samej gminie bez względu na osiągany wówczas wynik, co z reguły oznacza przegraną w wyborach poprzednich. Jest to kategoria tzw. kandydatów powtórzeniowych (Taylor, McEleney, 2015). Wcześniejsze doświadczenia w tym zakresie, mimo że w większości zakończone niepowodzeniem, mogą jednak budować przewagę w wyborach kolejnych, dlatego m.in., że wyborcy mogą takiego kandydata pamiętać. Sam kandydat ma z kolei doświadczenie w zabieganiu o głosy, co może wykorzystywać w przyszłych wyborach. Wcześniejsze kandydowanie weryfikowane jest w zakresie tej samej gminy i jeżeli dany kandydat w któryś z poprzednich wyborów kandydował w innej gminie, wówczas taki fakt odnotowywany nie jest. W praktyce udział takich „wędrujących” kandydatów jest marginalny. Podsumowując, jeżeli dany kandydat ubiegał się o urząd kierownika gminnej egzekutywy w tej samej gminie, kiedykolwiek w przeszłości, licząc od 2002 roku, wówczas taki kandydat będzie oznaczany przez $1, w$ innym przypadku przez 0 . Przykładowo dla analizowanych wyborów typu open race w 2014 roku, przez 1 w zakresie tej zmiennej oznaczeni zostaną kandydaci, którzy na przykład tylko w 2002 roku startowali w wyborach. Weryfikacja, czy mamy do czynienia z tą samą osobą, jest wieloetapowa i nawet zmiana nazwiska w przypadku kobiet nie „chroni” kandydatki przed identyfikacją.

Liczba ludności gminy do modeli wprowadzana jest w postaci logarytmu naturalnego. Z kolei liczba kandydatów/konkurentów w wyborach ze względu na ryzyko skorelowania z innymi zmiennymi niezależnymi do modeli wprowadzana jest w postaci rekodowanej.

Wśród tych zmiennych niezależnych brakuje prawdopodobnie najbardziej istotnej z punktu widzenia zwycięstwa w wyborach, w których nie kandyduje 
inkumbent. Tą zmienną jest oficjalne nominowanie następcy przez rezygnującego z ubiegania się o reelekcję, co potocznie określane jest jako tzw. „namaszczenie”. W 2014 roku instytucję namaszczenia aktywował prezydent Katowic Tadeusz Uszok, wskazując na swojego następcę Marcina Krupę, który ostatecznie wybory wygrał. Należy założyć, że oficjalne wskazanie następcy przez ustępującego ma wpływ na poparcie, choć ten wpływ może być różny i w głównej mierze moderowany jest przez liczbę ludności gminy. Instytucja „namaszczenia” następcy nie jest jednak w bazie danych wykazywana, bo zwłaszcza w przypadku gmin małoludnych szczególnie trudno ustalić, w której gminie ustępujący wskazał swojego następcę, ponieważ taka informacja, zwłaszcza w przypadku wyborów w 2006 i w 2010 roku, nie występuje w internetowych zasobach mediów lokalnych, albo media takie wówczas nie funkcjonowały.

Zmienną zależną w tej analizie jest poparcie w I turze wyborów, operacjonalizowane jako odsetek zdobytych głosów w tym podejściu. Wartości zmiennej zależnej ze względu na kształt rozkładu empirycznego nie logarytmizowano. Drugą zmienną zależną pozostaje zwycięstwo lub porażka wyborcza w danych wyborach, w pierwszym przypadku kodowana jako 1, w drugim jako 0.

\section{ZAŁOŻENIA}

W literaturze poświęconej zagadnieniu pozycjonowania na liście wyborczej najlepiej udokumentowano, że brak i niewystarczające informacje o kandydatach wśród wyborców zwiększają znaczenie miejsca kandydata na karcie wyborczej we wpływie na uzyskiwane poparcie i w efekcie na prawdopodobieństwo wygranej. W przypadku analizowanych wyborów, w których inkumbent nie kandyduje, efekt „luki informacyjnej” powinien się zwiększać. Brak inkumbenta w wyborach działa na wyborców destabilizująco, bo wówczas w odróżnieniu od wyborów, w których inkumbent kandyduje, wyborcy będą: dłużej podejmować decyzję, na kogo oddadzą swój głos; decyzja ta może ulegać zmianom; nadto wyborcy w wyborach typu open race bardziej zaangażują się w kampanię, (Moore, McGregor, Stephenson, 2017). Brak ubiegającego się o reelekcję w wyborach wprowadza chaos w świecie politycznych decyzji głosujących. Ludzie również i w tej sferze preferują raczej to, co było do tej pory, nad tym, co nowe i nieznane, co wyjaśnia tzw. głosowanie retrospektywne (Fiorina, 1981).

Uszczegółowienie wniosków w tym zakresie ujawnia, że znaczenie może mieć przede wszystkim pozycja pierwsza i ostatnia, choć bycie ostatnim na liście 
wyborczej może mieć większe znaczenie wówczas, gdy lista kandydatów jest długa, co w przypadku tych wyborów oznaczać może 3 i więcej kandydujących (mediana $=3$ kandydatów). Wówczas na wybór oddziaływać może efekt świeżości. W przypadku krótkich list kandydatów (2 kandydatów) większe znaczenie może mieć efekt pierwszeństwa. Ostatecznie przyjmuję, że w konkurencyjnych wyborach bezpośrednich organu wykonawczego gmin, rozgrywanych od 2006 roku, w których nie kandyduje inkumbent, w I turze:

H1: kandydaci z pierwszego miejsca listy otrzymywać będą z tego tytułu wyższe poparcie;

$\mathrm{H} 2$ : oraz kandydaci z ostatniego miejsca listy otrzymywać będą z tego tytułu wyższe poparcie.

Jako wtórne do powyższych założeń przyjmuję, że obydwa miejsca brzegowe na liście zwiększają istotnie szanse na zwycięstwo wyborcze.

\section{ANALIZA}

Znaczenie pozycji na liście dla uzyskanych głosów w I turze oraz szans wygranej w wyborach od 2006 roku, w których uprzednio rządzący nie kandyduje, pomogą nam zrozumieć dane w tabeli 1.

Tabela 1. Wygrywający wg pozycji na liście w wyborach konkurencyjnych bez obecności inkumbenta od 2006 roku

\begin{tabular}{|c|c|c|c|c|c|c|c|c|c|c|c|c|c|c|c|}
\hline & & & \multicolumn{1}{|c|}{ N wygranych wg pozycji na liście } \\
\hline \# kandydatów & \% starć & $\mathrm{N}$ & oczekiwane & $\mathbf{1}$ & $\mathbf{2}$ & $\mathbf{3}$ & $\mathbf{4}$ & $\mathbf{5}$ & $\mathbf{6}$ & $\mathbf{7}$ & $\mathbf{8}$ & $\mathbf{9}$ & $\mathbf{1 0}$ & $\mathbf{1 1}$ \\
\hline $1 \mathrm{z} 2$ & 18,9 & 137 & 68,5 & 76 & 61 & & & & & & & & & \\
\hline $1 \mathrm{z} 3$ & 22,5 & 163 & 54,3 & 49 & 51 & 63 & & & & & & & & \\
\hline $1 \mathrm{z} 4$ & 24,3 & 176 & 44 & 51 & 48 & 38 & 39 & & & & & & & \\
\hline $1 \mathrm{z} 5$ & 16,4 & 119 & 23,8 & 23 & 22 & 19 & 29 & 26 & & & & & & \\
\hline $1 \mathrm{z} 6$ & 10,8 & 78 & 13 & 15 & 9 & 15 & 17 & 10 & 12 & & & & & \\
\hline $1 \mathrm{z} 7$ & 3,9 & 28 & 4 & 3 & 5 & 3 & 3 & 2 & 3 & 9 & & & & \\
\hline $1 \mathrm{z} 8$ & 1,8 & 13 & 1,6 & 1 & 5 & 3 & 0 & 2 & 0 & 0 & 2 & & & \\
\hline $1 \mathrm{z} 9$ & 1,0 & 7 & 0,7 & 0 & 1 & 3 & 1 & 0 & 1 & 0 & 0 & 1 & & \\
\hline $1 \mathrm{z} 10$ & 0,1 & 1 & 0,1 & 0 & 0 & 0 & 0 & 1 & 0 & 0 & 0 & 0 & 0 & \\
\hline $1 \mathrm{z} 11$ & 0,3 & 2 & 0,18 & 1 & 0 & 0 & 0 & 0 & 0 & 0 & 0 & 0 & 0 & 1 \\
\hline
\end{tabular}

Źródło: obliczenia własne na podst. PKW. 
Widzimy tam, że obserwowane wygrane w wyborach różnią się od rozkładu oczekiwanego. Przykładowo dla wyborów z czterema kandydatami (w sumie, w wyborach w 2006, 2010 i w 2014 roku, takich starć było 176, czyli w co czwartych takich wyborach startowało czterech kandydatów - 24,3\%) oczekujemy, że kandydaci na każdym miejscu listy powinni wygrywać po 44 razy $(176 / 4=44)$. W rzeczywistości obserwujemy, że w takich wyborach wyższa pozycja na liście wyborczej to większe szanse wygranej. Kandydujący z miejsca pierwszego w takich wyborach zwyciężyli w sumie 51 razy, a kandydujący z miejsca drugiego zwyciężali 48 razy. Podobna tendencja im wyżej na liście tym lepiej dla kandydata dotyczy wyborów, w których kandydowały dwie osoby. W takim przypadku oczekiwany rozkład wynosi 68,5 dla miejsca pierwszego i drugiego na liście, tymczasem pierwsi na liście wygrali 76 razy, a drudzy, czyli w tym przypadku ostatni na liście, wygrali tylko 61 razy. Jednak przyglądając się wyborom, w których kandydowały w sumie 3 osoby, widzimy odwrócenie tej zależności, bo w tych starciach promowani są ostatni na liście i im niższa pozycja na liście, tym wyższa szansa na wygraną. W tym przypadku pierwsi na liście byli niedowartościowani (obserwowanych wygranych 49 , a oczekiwanych 54,3 ), a ostatni na liście byli przewartościowywani (obserwowanych wygranych 63). Dla wyborów typu open race w charakteryzowanym okresie czasu, w których kandydowało 5 osób, obserwujemy raczej dowartościowanie ostatnich pozycji na liście niż pozycji pierwszej. W wyborach z sześcioma kandydatami najczęściej wygrywała osoba na pozycji czwartej (17 razy), następnie na pozycji pierwszej i trzeciej (po 15 razy). Wreszcie tam, gdzie kandydowało siedem osób, najczęściej zwyciężali ostatni na liście (9 razy), przewartościowaniu ulega także pozycja druga (5 krotna wygrana).

Wynika z tego, że pozycja na liście ma wpływ na szanse wygranej, po drugie najwyższe szanse na sukces mają pierwsi i ostatni na liście. Trzeba tu jednak pamiętać o wcześniejszym zastrzeżeniu, że nie znamy w tym przypadku skali namaszczeń.

Przystępując do ewaluacji przyjętych założeń, przeprowadzono analizę na zmiennych kontrolnych, weryfikowanych zmiennych niezależnych oraz zmiennych kluczowych pod względem celów analizy, tak aby wykluczać i minimalizować obciążenia predykcji. W wyniku szeregu takich działań stwierdzono, że:

1. pierwsza i ostatnia pozycja na liście wyborczej w danych wyborach zwiększają szansę zwycięstwa w tych wyborach, nawet gdy z bazy danych usuniemy wszystkich tych, którzy kandydowali kiedykolwiek w wyborach poprzednich (tabela 2 , model 1 i 2 ); 
2. mimo przekroczenia progu istotności możemy przyjąć, że pierwsza pozycja na liście wyborczej w wyborach (t), zwiększa prawdopodobieństwo kandydowania w wyborach kolejnych $(\mathrm{t}+1)$, a ostatnia pozycja na liście $\mathrm{w}$ wyborach $(\mathrm{t})$ tak nie oddziałuje, nawet gdy $\mathrm{z}$ bazy danych usuniemy: a) wszystkich tych, którzy kandydowali kiedykolwiek w wyborach poprzednich; i b) zwyciężyli w wyborach (t), (tabela 2, model 3 i 4).

Z powyższych wniosków wynika, że zajmowanie pierwszego miejsca na liście w wyborach aktualnych (t), z nieustalonych przyczyn zwiększa prawdopodobieństwo kandydowania tych osób w wyborach kolejnych $(t+1)$. Bowiem na ten fakt nie wpływa ani kandydowanie w poprzednich wyborach, ani zwycięstwo w wyborach aktualnych (t), które naturalnie zwiększałoby presję na ubieganie się o reelekcję. Prawdopodobną przyczyną takiego zachowania mogłoby być wyższe poparcie w I turze wyborów bieżących oraz przejście do II tury. Tak jednak nie jest, bo ostatni na liście wyborczej w zestawieniach z różną liczbą kandydatów w wyborach oraz z włączaniem i wyłączaniem kandydujących w przeszłości zawsze wykazują wyższe poparcie niż pierwsi na liście. Mimo tego kandydaci na ostatnim miejscu listy w wyborach bieżących (t) nie wykazują skłonności do kandydowania w wyborach kolejnych $(\mathrm{t}+1)$. Pod uwagę weźmy także, że w modelu 3 została nieznacznie (o 0,007; gdzie $p=0,056)$ przekroczona istotność dla zajmujących pierwsze miejsce na liście w określeniu ich szans na kandydowanie w wyborach kolejnych $(t+1)$. Jednak dla zajmujących ostatnie miejsce na liście w wyborach ( $\mathrm{t}$ ) w określeniu ich szans na kandydowanie w wyborach kolejnych $(t+1)$ to przekroczenie jest już znaczące $(\mathrm{p}=0,490)$. Podobne wnioski w tym zakresie sugeruje rozkład empiryczny macierzy danych w tabeli krzyżowej, przy df $=1$; $p$ dla Chi-kwadrat=0,061 dla pozycji pierwszej na liście; oraz $\mathrm{df}=1 ; p$ dla Chi-kwadrat $=0,501$ dla pozycji ostatniej na liście $\mathrm{w}$ zestawieniu $\mathrm{z}$ kandydowaniem lub nie $\mathrm{w}$ wyborach kolejnych $(\mathrm{t}+1)$. Rozkład w danych tabeli krzyżowej jest bliższy rozkładowi intencjonalnemu dla pozycji pierwszej na liście niż dla ostatniej pozycji na liście.

Ostatecznie w tabeli 2 widzimy estymację przy użyciu regresji logistycznej. W modelach 1 i 2 zmienna zależna to zwycięstwo (oznaczone jako 1) lub porażka (oznaczona jako 0) w wyborach aktualnych (t). W modelach tych bierze się pod uwagę wybory konkurencyjne w 2006, 2010 i w 2014 roku rozgrywane bez obecności inkumbenta, a z bazy danych dla tych modeli wyłączono kandydujących kiedykolwiek w wyborach poprzednich. Z kolei zmienną zależną dla modeli 3 i 4 jest kandydowanie (oznaczone jako 1) lub niekandydowanie (oznaczone jako 0$)$ w wyborach kolejnych $(t+1)$. Dla tych estymacji z bazy danych oprócz 
Tabela 2. Modele regresji logistycznej określające szanse zwycięstwa w wyborach $(\mathrm{t})-1$ i 2 oraz kandydowania w wyborach $(\mathrm{t}+1)-3$ i 4

\begin{tabular}{|c|c|c|c|c|c|c|c|c|}
\hline \multirow{2}{*}{$\begin{array}{c}\text { zależna: zwycięstwo/porażka } \\
\text { w wyborach }(\mathrm{t})\end{array}$} & \multicolumn{4}{|c|}{1} & \multicolumn{4}{|c|}{2} \\
\hline & B & SE & $p$ & $\operatorname{Exp}(B)$ & B & SE & $p$ & $\operatorname{Exp}(B)$ \\
\hline płeć $(\mathrm{K}=0 ; \mathrm{M}=1)$ & 0,166 & 0,136 & 0,224 & 1,180 & 0,179 & 0,137 & 0,190 & 1,196 \\
\hline komitet bezpartyjny (tak=1; nie $=0$ ) & 0,625 & 0,123 & 0,000 & 1,868 & 0,621 & 0,123 & 0,000 & 1,861 \\
\hline $\begin{array}{l}\text { wykształcenie wyższe }(\operatorname{tak}=1 ; \\
\text { nie }=0)\end{array}$ & 0,576 & 0,143 & 0,000 & 1,779 & 0,567 & 0,144 & 0,000 & 1,763 \\
\hline wiek (w dekadach) & $-0,140$ & 0,054 & 0,009 & 0,869 & $-0,140$ & 0,054 & 0,010 & 0,869 \\
\hline $\begin{array}{l}\text { pierwsze miejsce na liście ( } \operatorname{tak}=1 \\
\text { nie }=0 \text { ) }\end{array}$ & 0,333 & 0,111 & 0,003 & 1,395 & & & & \\
\hline $\begin{array}{l}\text { ostatnie miejsce na liście }(\operatorname{tak}=1 \\
\text { nie }=0)\end{array}$ & & & & & 0,390 & 0,111 & 0,000 & 1,477 \\
\hline \multirow{2}{*}{$\begin{array}{c}\text { stała } \\
\mathrm{N}\end{array}$} & $-1,700$ & 0,335 & 0,000 & 0,183 & $-1,716$ & 0,336 & 0,000 & 0,180 \\
\hline & \multicolumn{4}{|c|}{2295} & \multicolumn{4}{|c|}{2295} \\
\hline \multirow[b]{2}{*}{$\begin{array}{l}\text { zależna: kandydowanie w wyborach } \\
\qquad \mathrm{t}+1\end{array}$} & \multicolumn{4}{|c|}{3} & \multicolumn{4}{|c|}{4} \\
\hline & B & SE & $p$ & $\operatorname{Exp}(B)$ & B & SE & $p$ & $\operatorname{Exp}(B)$ \\
\hline płeć $(\mathrm{K}=0 ; \mathrm{M}=1)$ & 0,337 & 0,216 & 0,119 & 1,401 & 0,337 & 0,216 & 0,119 & 1,400 \\
\hline komitet bezpartyjny $(\operatorname{tak}=1 ;$ nie $=0)$ & $-0,330$ & 0,158 & 0,037 & 0,719 & $-0,325$ & 0,158 & 0,040 & 0,723 \\
\hline $\begin{array}{l}\text { wykształcenie wyższe }(\mathrm{tak}=1 \\
\text { nie }=0)\end{array}$ & 0,123 & 0,196 & 0,530 & 1,131 & 0,129 & 0,196 & 0,511 & 1,137 \\
\hline wiek (w dekadach) & $-0,382$ & 0,080 & 0,000 & 0,683 & $-0,381$ & 0,080 & 0,000 & 0,683 \\
\hline $\begin{array}{l}\text { pierwsze miejsce na liście }(\operatorname{tak}=1 ; \\
\text { nie }=0)\end{array}$ & 0,322 & 0,169 & 0,056 & 1,380 & & & & \\
\hline $\begin{array}{l}\text { ostatnie miejsce na liście ( } \operatorname{tak}=1 \text {; } \\
\text { nie }=0)\end{array}$ & & & & & $-0,128$ & 0,185 & 0,490 & 0,880 \\
\hline \multirow{2}{*}{$\begin{array}{c}\text { stała } \\
\mathrm{N}\end{array}$} & $-0,526$ & 0,471 & 0,264 & 0,591 & $-0,428$ & 0,472 & 0,365 & 0,652 \\
\hline & \multicolumn{4}{|c|}{1750} & \multicolumn{4}{|c|}{1750} \\
\hline
\end{tabular}

Źródło: obliczenia własne na podst. PKW. 
wspomnianego wyłączenia usunięto też obserwacje charakteryzujące się zwycięstwem w wyborach $(\mathrm{t})$.

Wnioski płynące $\mathrm{z}$ modeli 1 i $2 \mathrm{w}$ tabeli 2 sugerują, że pozycjonowanie na pierwszym i ostatnim miejscu listy wyborczej pomaga wygrać wybory, co powinno znajdować przełożenie na odsetek głosów w I turze. Wiemy też, że czynnikiem obciążeniowym predykcji może być fakt kandydowania w którychkolwiek z wyborów poprzednich. Ubogaceni w te wnioski przystępujemy do weryfikacji wpływu brzegowych pozycji na liście wyborczej na wielkość poparcia w I turze wyborów konkurencyjnych rozgrywanych w trybie open race od 2006 roku. W tabeli 3 przedstawiono propozycję modeli regresji liniowej w różnych wariantach doboru obserwacji i z podmianą zmiennej kontrolnej (rekodowana liczba konkurentów w danych wyborach i logarytm liczby ludności szacowany dynamicznie wg stanu na 31.12. danego roku wyborczego: 2006, 2010 lub 2014).

W tabeli 3 modele 1, 2 i 3 budowano $\mathrm{z}$ wyłączeniem $\mathrm{z}$ bazy danych tych, którzy kiedykolwiek kandydowali w wyborach poprzednich, do czego przesłankę stanowią wcześniejsze wnioski, sugerujące, że kandydujący z pierwszych pozycji w wyborach $(\mathrm{t})$ mają większą motywację do kandydowania w wyborach kolejnych $(\mathrm{t}+1)$. Poza tym udział ponownie kandydujących będzie zakłócać oddziaływanie pierwszej pozycji na liście wyborczej, ponieważ, pierwsi na liście w wyborach poprzednich (t) mają większe od pozostałych szanse bycia pierwszymi na liście w wyborach kolejnych $(\mathrm{t}+1)$, co ma związek $\mathrm{z}$ wielkością ludnościową gminy, bo przekłada się na liczbę kandydujących. Dlatego liczbę kandydujących w wyborach operacjonalizowano w ten sposób, że w sytuacji, kiedy tych kandydatów było co najmniej trzech, wówczas taki stan kodowano jako 1, w przeciwnym razie jako 0. Do modelu nie wprowadzano bezwzględnej liczby kandydatów, bowiem na taką postać zmiennej wrażliwy jest testowany predyktor: pierwsza pozycja na liście wyborczej. Wynika to również z tego, że im więcej kandydujących, tym większe rozproszenie głosów i ich ubytek dla pozycji pierwszej. Liczba kandydujących to również najsilniejszy predyktor w wyborach bez inkumbenta. Dlatego inny sposób operacjonalizowania tej zmiennej w modelu powoduje wytracenie istotności wpływu pierwszego miejsca na liście, co jest wynikiem wzrastającego poziomu korelacji tych zmiennych niezależnych, a nie rzeczywistym ubytkiem wpływu pierwszej pozycji na liście wyborczej. Model $3 \mathrm{w}$ tabeli 3 sugeruje, że ostania pozycja na liście wyborczej dodatkowo zyskuje w wyborach, w których mamy 3 i więcej kandydujących, zatem ostatni na liście wyborczej mogą liczyć na zwiększenie poparcia w większych ludnościowo gminach. Model 3 przedstawia też jedyny możliwy do uzyskania istotny efekt interakcyjny w zakresie testowa- 


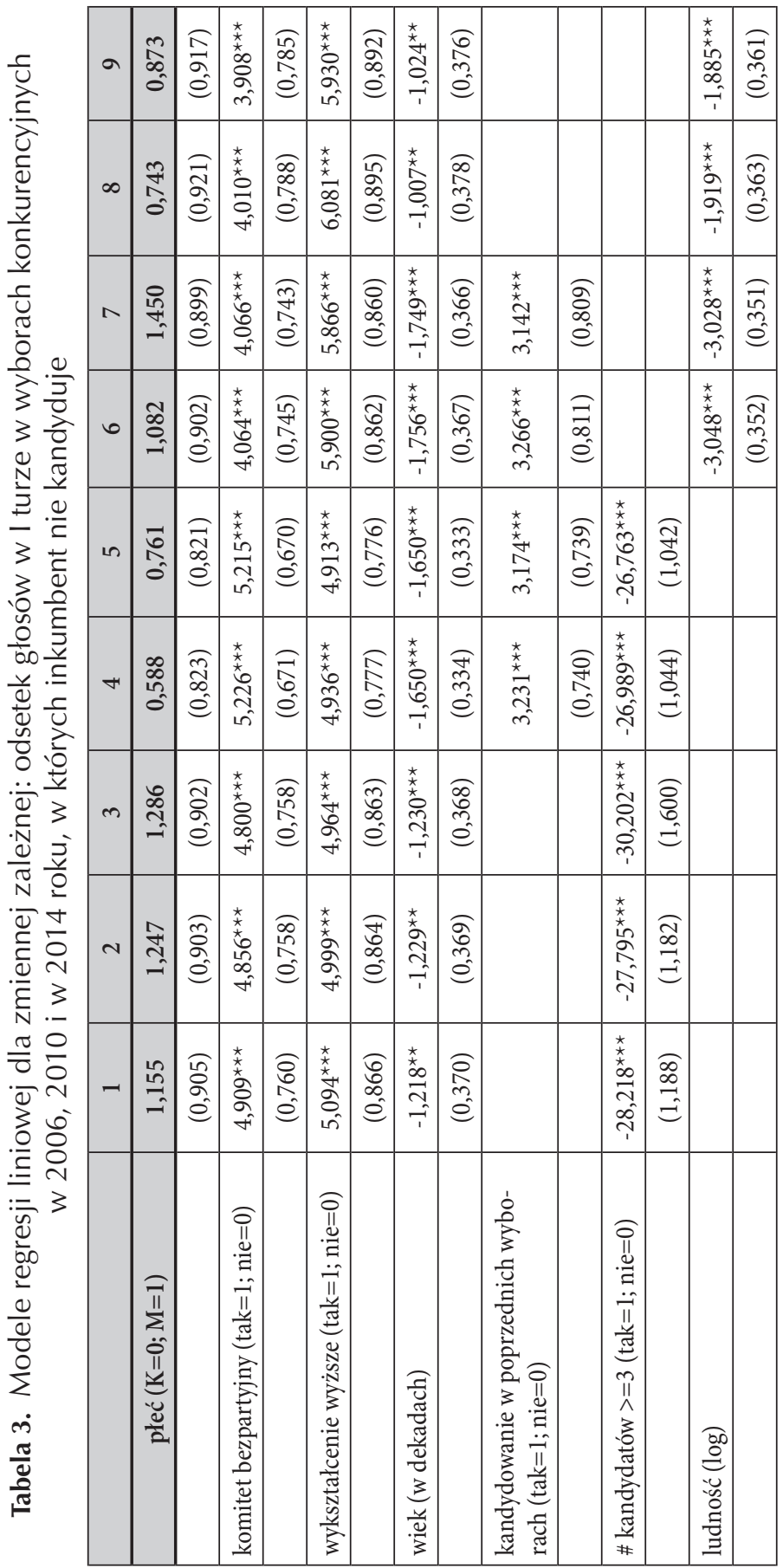




\begin{tabular}{|c|c|c|c|c|c|c|c|c|c|c|c|c|c|}
\hline$a$ & $\begin{array}{c}m \\
\infty \\
0 \\
0\end{array}$ & & & 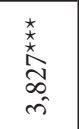 & $\begin{array}{l}\widehat{\widehat{A}} \\
\infty \\
\hat{e}\end{array}$ & & & 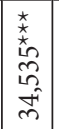 & $\begin{array}{l}\widehat{\infty} \\
\infty \\
\tilde{c} \\
\tilde{c}\end{array}$ & i̊ & 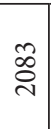 & 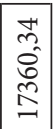 & 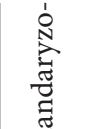 \\
\hline$\infty$ & $\frac{m}{\stackrel{7}{*}}$ & 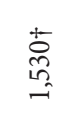 & 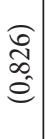 & & & & & 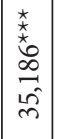 & $\begin{array}{l}\widetilde{\hat{n}} \\
\infty \\
\hat{\sigma} \\
\hat{\sigma}\end{array}$ & in & $\begin{array}{l}\mathscr{0} \\
\stackrel{\sim}{\sim}\end{array}$ & $\mid \begin{array}{c}\infty \\
\sim \\
\infty \\
\infty \\
\tilde{n} \\
\simeq\end{array}$ & 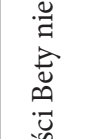 \\
\hline$\wedge$ & $\stackrel{8}{4}$ & & & $\begin{array}{l}\stackrel{\star}{c} \\
\stackrel{x}{\star} \\
\stackrel{\infty}{\infty} \\
\infty \\
\infty \\
i n\end{array}$ & $\begin{array}{l}\hat{\widehat{n}} \\
\hat{\mathfrak{e}} \\
\hat{e}\end{array}$ & & & 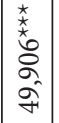 & 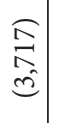 & 亏े & $\overrightarrow{\widetilde{ন}}$ & 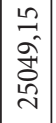 & 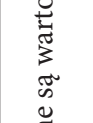 \\
\hline 0 & $\stackrel{\substack{0 \\
0 \\
0}}{-1}$ & 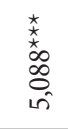 & 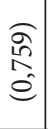 & & & & & 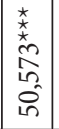 & 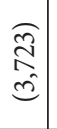 & $\stackrel{\infty}{\infty}$ & $\overrightarrow{\widetilde{ડ}}$ & 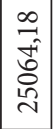 & 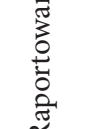 \\
\hline in & $\begin{array}{l}\bar{b} \\
\hat{0}\end{array}$ & & & 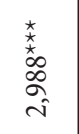 & $\begin{array}{l}\tilde{\hat{e}} \\
\hat{e} \\
\hat{e}\end{array}$ & & & 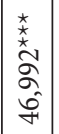 & $\begin{array}{l}\widehat{a} \\
\vec{a} \\
\hat{\mathfrak{d}}\end{array}$ & ले & $\overrightarrow{\widehat{ડ}}$ & 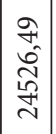 & $\begin{array}{l}\dot{E} \\
\vec{E} \\
\dot{0} \\
\vec{D}\end{array}$ \\
\hline+ & $\begin{array}{l}\infty \\
\infty \\
1 \\
0 \\
0\end{array}$ & 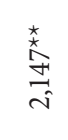 & 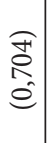 & & & & & 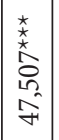 & $\begin{array}{l}\widetilde{2} \\
\infty \\
\mathfrak{d}\end{array}$ & ڤें & $\overrightarrow{\widetilde{ડ}}$ & 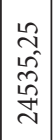 & $\begin{array}{l}\text { 20 } \\
0 \\
\hat{v} \\
\text { 2. }\end{array}$ \\
\hline$m$ & 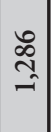 & & & 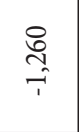 & $\begin{array}{l}\vec{\exists} \\
\vec{d} \\
\vec{d}\end{array}$ & 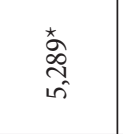 & 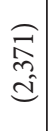 & 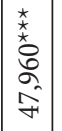 & $\begin{array}{l}\text { ôt } \\
\text { b } \\
\text { d }\end{array}$ & 원 & $\stackrel{2}{\stackrel{\aleph}{~}}$ & 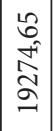 & $\begin{array}{l}\overrightarrow{0} \\
\hat{\theta} \\
\stackrel{v}{2}\end{array}$ \\
\hline$\sim$ & $\underset{-}{\stackrel{N}{二}}$ & & & 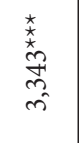 & 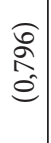 & & & 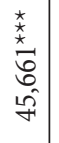 & $\begin{array}{l}\widehat{\approx} \\
\stackrel{m}{d} \\
\mathfrak{d}\end{array}$ & 高 & 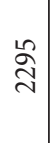 & 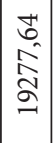 & $\begin{array}{l}\beth \\
\overrightarrow{8} \\
\dot{0}\end{array}$ \\
\hline- & $\begin{array}{l}10 \\
\\
=\end{array}$ & 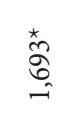 & $\begin{array}{l}\overparen{2} \\
\stackrel{\nwarrow}{e} \\
\hat{e}\end{array}$ & & & & & 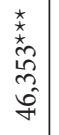 & 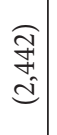 & ते & 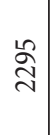 & 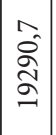 & $\begin{array}{l}0 \\
0 \\
3 \\
3\end{array}$ \\
\hline & 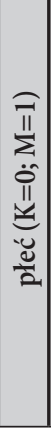 & 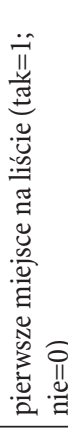 & & 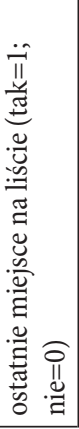 & & 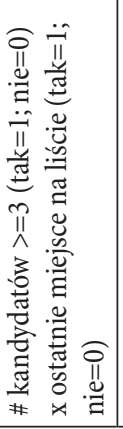 & & $\begin{array}{l}\frac{\pi}{\pi} \\
\text { 蒈 }\end{array}$ & & 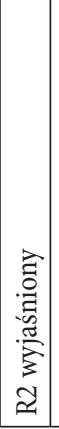 & $z$ & 妥 & 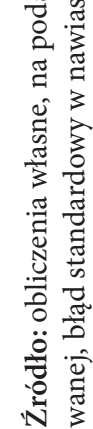 \\
\hline
\end{tabular}


nych zmiennych kontrolnych (w roli moderatorów) i zmiennych weryfikowanych (pierwsza i ostatnia pozycja na liście wyborczej).

Modele 4 i 5 w tabeli 3 przedstawiają estymację, włączając tych, którzy kiedykolwiek od 2002 roku kandydowali już poprzednio przynajmniej w jednych wyborach, i uwzględniając ten predyktor w modelach. Modele te względem poprzednich charakteryzuje spadek jakości ich dopasowania. Wreszcie modele 6 i 7 zbudowano, zastępując liczbę kandydatów logarytmem naturalnym z liczby ludności gminy, szacowanym każdorazowo dla danych wyborów, przy uwzględnieniu kiedykolwiek kandydujących od 2002 roku i wprowadzając ten predyktor do modelu. Powoduje to ponowny spadek jakości dopasowania oraz obniżenie efektywności modeli 6 i 7 o ok. 15\% względem modeli poprzednich. Sugeruje to jednocześnie, że w wyborach bez inkumbenta, głosujący są mocno zdezorientowani, a sytuacji nie poprawiają w tym przypadku charakterystyki kandydatów (np. wykształcenie czy afiliacja komitetu wyborczego), które nie są w stanie efektywnie ogniskować głosów. Ten z kolei wniosek potwierdza domniemywany znaczący wpływ „namaszczenia” następcy, jednak informacjami w tym zakresie tu nie dysponujemy.

Jak już dowiedziono, płeć w wyborach bez inkumbenta przestaje być efektywnym predyktorem (Bartnicki, 2017). Istotny wpływ wykazują, czego można się spodziewać, wykształcenie wyższe, wiek czy fakt kandydowania w przeszłości od 2002 roku licząc. Wyborcy premiują też kandydatów afiliowanych przy komitetach niepartyjnych. Lecz nawet, uwzględniając w tych modelach liczbę ludności gminy, modele te wyjaśniają mniej niż 10\% zmienności głosów zdobywanych w I turach w wyborach bez obecności inkumbenta.

Ostatecznie, aby sprawdzić odporność oddziaływania brzegowych pozycji na liście wyborczej zaproponowano dwa modele wzmocnione 8 i 9 . Konstrukcja tych modeli zakłada: utrzymanie nisko interferującego z testowanymi zmiennymi predyktora; logarytm $z$ liczby ludności gminy w roku wyborów; eliminację $\mathrm{z}$ analizowanych danych kandydujących kiedykolwiek w poprzednich wyborach; podwyższenie progu analizy o wybory rozgrywane w obecności co najmniej 3 kandydatów. Tak skonstruowane modele sugerują wytracanie istotnego wpływu pierwszej pozycji na liście i stabilność oddziaływania pozycji ostatniej, co potwierdza i rozszerza wnioski z dotychczasowych modeli.

Podsumowując weryfikację założeń, modele 1 i 2 w tabeli 2 oraz modele z tabeli 3 sugerują pozytywny wpływ brzegowych pozycji na karcie wyborczej na odsetek głosów w I turze, co przekłada się na istotny wzrost szans zwycięstwa w wyborach. Pierwsza pozycja na karcie do głosowania daje od 1,6 do 5\% 
więcej głosów w I turze. Ostatni na karcie mogą liczyć z tego tytułu na wzrost poparcia w I turze od 3\% do prawie 6\%. Przewaga ostatnich na karcie jest wyższa i stabilniejsza, niż przewaga wykazywana przez pierwszych. Poza tym ostatnie miejsca są dodatkowo premiowane, kiedy w wyborach startuje trzech i więcej kandydatów, a pierwsze miejsca na karcie do głosowania na tym tracą do tego stopnia, że ich przewaga traci walor istotności statystycznej, jeżeli brać pod uwagę wybory z co najmniej trzema kandydatami ( $p=0,064 \mathrm{w}$ modelu 8 , w tabeli 3). Jednak generalnie, jeżeli nie można być na miejscu ostatnim, to i tak opłaca się być na miejscu pierwszym.

\section{PODSUMOWANIE}

Przedkładany artykuł odkrywa tendencje rządzące konkurencyjnymi wyborami bezpośrednimi organów wykonawczych gmin w trybie open race i niweluje lukę w dotychczasowej rodzimej literaturze odnoszącej się do tego problemu. Wypracowane w tym zakresie wnioski pokrywają się z obserwacjami pochodzącymi z różnych miejsc na świecie. Podobnie zresztą jak i wnioski dotyczące różnych innych aspektów tych wyborów, jak choćby dominacji inkumbentów (Bartnicki, 2017) czy czynników zwiększających szansę reelekcji wójtów, burmistrzów i prezydentów miast (Bartnicki, 2018). Wszystkie te wnioski w różnych aspektach ubogacają nasz stan wiedzy na temat praw rządzących wyborami bezpośrednimi wójtów, burmistrzów i prezydentów miast. Wiele pozostaje jeszcze w tym zakresie do zbadania, jak choćby rozwinięcie głównego wątku przedmiotowej analizy na pozostałe wybory rozgrywane w obecności inkumbentów. W zakresie tych wyborów interesujące wydaje się też udzielenie odpowiedzi na szereg pytań badawczych obecnych w literaturze światowej, a dotyczących analogicznych i innych wyborów, jak choćby: określenie prawdopodobieństwa kandydowania w kolejnych wyborach (Castro, Martins, 2011); określenie wpływu zmiennych wysoko przetworzonych, np. czasopism lokalnych pozostających w domenie urzędów gmin, na zwiększenie szans wyborczych w gminach relatywnie niewielkich pod względem liczby ludności (Trounstine, 2016); określenie wielkości efektu inkumbenta, z tytułu wcześniejszego sprawowania władzy przy użyciu metod quasi-eksperymentalnych (np. Trounstine, 2011; Freier, 2015; Titiunik, 2011; Mcdonald, 2014); określenie szans reelekcji na podstawie analiz danych wzdłużnych (np. Sarpietro, 2014); warto jeszcze nadmienić analizy dotyczące cyklu budżetowego i jego składowych (np. Veiga, Veiga, 2007); i wiele jeszcze 
innych, szczególnie, kiedy w literaturze rodzimej szczególnej eksploatacji i w konsekwencji moim zdaniem przewartościowaniu podlega głównie wątek partyjnej i niepartyjnej afiliacji kandydata i jego następstw (np. Bukowski, Flis, Hess, Szymańska, 2011; Drzonek, 2013).

Rekapitulując, udowodniono, że miejsce na liście wyborczej ma wpływ na poparcie wyborcze w konkurencyjnych wyborach bezpośrednich organu wykonawczego gminy w 2006, 2010 i w 2014 roku, w których nie kandyduje uprzednio rządzący. Wyższe poparcie w takich wyborach w I turze zdobywają zajmujący pierwsze i przede wszystkim ostatnie pozycje na liście w porównaniu z pozostałymi. W tym zakresie warto się zastanowić nad możliwością losowania pozycji na listach wyborczych przy obsadzaniu tego typu stanowisk. W aktualnym stanie rzeczy zachowanie kolejności alfabetycznej przy wyznaczaniu pozycji na karcie wyborczej z góry faworyzuje kandydatów na pozycjach brzegowych. Renta $\mathrm{z}$ tego tytułu nie jest na tyle silna, aby przesądzać o zwycięstwie, jednak szalę zwycięstwa przechyla, bo istotnie dowartościowuje kandydatów wg ich miejsca na karcie wyborczej.

\section{BIBLIOGRAFIA:}

Alvarez, M.R., Sinclair, B., Hasen, R.L. (2006). How Much Is Enough? The "Ballot Order Effect" and the Use of Social Science Research in Election Law Disputes. Election Law Journal, 5(1), s. 4-56.

Bartnicki, S. (2017). Determinanty poparcia kandydatów podczas wyborów gminnego organu wykonawczego. Studia Wyborcze, 23, s. 107-129.

Bartnicki, S. (2018). Uwarunkowania dominacji ubiegających się o reelekcję do organu wykonawczego gmin w wyborach w 2014 roku, w gminach nie będących miastami na prawach powiatu. Samorzad Terytorialny, w druku.

Blom-Hansen, J., Elklit, J.,Serritzlew, S., Villadsen, L.R. (2014). Ballot Position and Election Results: Evidence from a Natural Experiment. Draft, Prepared for presentation at the annual meeting of the Danish Political Science Association, Denmark, 23-24 October, 2014. Pobrane z: http://dpsa.dk/papers/Blom-Hansen\%20et\%20al\%20 \%28DSS\%29\%2020141610.pdf.

Bukowski, M., Flis, J., Hess, A., Szymańska, A. (2011). Opcja czy osoba? Upartyjnienie versus personalizacja w wyborach samorzadowych. Kraków: Wydawnictwo Uniwersytetu Jagiellońskiego.

Brockington, D. (2003). A Low Information Theory of Ballot Position Effect. Political Behavior 25(1), s. 1-27. DOI: https://doi.org/10.1023/A:1022946710610.

Castro, V., Martins, R. (2011). Mayors Reelection Choice and the Economy: Evidence from

Portugal. NIPE, Working Paper 06. 
Chen, E., Simonovits, G., Krosnick, J.A., Pasek, J. (2014). The Impact of Candidate Name Order on Election Outcomes in North Dakota. Electoral Studies, 35, s. 115-122. DOI: 10.1016/j.electstud.2014.04.018.

Darcy, R., McAllister, I. (1990). Ballot Position Effects. Electoral Studies, 9(1), s. 5-17. Drzonek, M. (2013). Reelekcje prezydentów miast w wyborach bezpośrednich w Polsce. Kraków: Wydawnictwo Dante.

Faas, T., Schoen, H. (2006). The Importance of Being First: Effects of Candidates List Positions in the 2003 Bavarian State Election. Electoral Studies, 25(1), s. 91-102.

Fiorina, M. (1981), Retrospective Voting in American National Elections. New Haven: Yale University Press.

Freier, R. (2015). The Mayor's Advantage: Casual Evidence on Incumbency Effects in German Mayoral Elections. European Journal of Political Economy, 40, s. 16-30. DOI: 10.1016/j.ejpoleco.2015.07.005.

Gelman, A., King, G. (1990). Estimating Incumbency Advantage Without Bias. American Journal of Political Science, 34, s. 1142-1164.

Hajnal, Z., Lewis, P., Louch, H. (2002). Municipal Elections in California: Turnout, Timing, and Competition. Pobrane z: http://www.ppic.org/content/pubs/report/R_302ZHR.pdf.

Halamska, M. (2013). Wiejska Polska na początku XXI wieku. Rozważania o gospodarce i społeczeństwie. Warszawa: Wydawnictwo Naukowe Scholar.

Janik, K. (2007). Bezpośrednie wybory wójtów, burmistrzów i prezydentów miast geneza i doświadczenia dwóch elekcji. W: J. Marszałek-Kawa (red.), Samorząd terytorialny. Studium politologiczne (s. 186-198). Toruń: Dom Wydawniczy Duet.

Kim, N., Krosnick, J., Casasanto, D. (2015). Moderators of Candidate Name-Order Effects in Elections: An Experiment. Political Psychology, 36(5), s. 525-542. DOI: 10.1111 pops.12178.

King, A., Leigh, A. (2009). Are Ballot Order Effects Heterogeneous?. Social Science Quarterly, 90(1), s. 71-87.

Macdonald, B. (2014). Estimating Incumbency Advantages in African Politics: Regression discontinuity Evidence from Zambian Parliamentary and Local Government Elections. Working Paper Series 2014, London School of Economics and Political Science. Pobrane z: http://www.lse.ac.uk/internationalDevelopment/pdf/Dissertations/WP151.pdf.

Magnier, A. (2006). Strong Mayors? On Direct Election and Political Enterpreneurship. W: H. Bäck, H. Heinelt, A. Magnier (red.), The European Mayor. Political Leaders in the Changing Context of Local Democracy (s. 353-376). Wiesbaden: VS Verlag für Sozialwissenschaften.

Marcinkiewicz, K. (2014). Electoral Contexts That Assist Voter Coordination: Ballot Position Effects in Poland. Electoral Studies, 33, s. 322-334. DOI: http://dx.doi. org/10.1016/j.electstud.2013.07.018.

Marcinkiewicz, K., Stegmaier, M. (2015). Ballot Position Effects Under Compulsory and Optional Preferential-List PR Electoral Systems. Political Behavior, 37(2), s. 465-486. DOI: 10.1007/s11109-014-9294-0. 
Meredith, M., Salant, Y. (2013). On the Causes and Consequences of Ballot Order Effects. Political Behavior, 35(1), s. 175-197. DOI: 10.1007/s11109-011-9189-2.

Miler, J.M., Krosnick, J.A. (1998). The Impact of Candidate Name Order on Election Outcomes. Public Opinion Quarterly, 62(3), s. 291-330.

Moore, A.A., McGregor, M.R., Stephenson, L.B. (2017). Paying Attention and the Incumbency Effect: Voting Behavior in the 2014 Toronto Municipal Election. International Political Science Review, 38(1), s. 85-98. DOI: 10.1177/0192512115616268.

Oliver, J.E., Ha, S.E., Callen, Z. (2012). Local Elections and the Politics of Small-Scale Democracy. Princeton: Princeton University Press.

Piasecki, A. (2004). Wybory parlamentarne, samorząowe, prezydenckie 1998-2002. Torun: Wydawnictwo Adam Marszałek.

Regulski, J. (2000). Samorząd III Rzeczpospolitej. Warszawa: PWN.

Sarpietro, S. (2014). Determinants of Reelection in Portuguese Municipal Elections. Pobrane z: http://tesi.eprints.luiss.it/12599/1/sarpietro-silvia-tesi-2014.pdf.

Spierings, N., Jacobs, K. (2014). Getting Personal? The Impact of Social Media on Preferential Voting. Political Behavior, 36(1), s. 215-234. DOI: https://doi.org/10.1007/ s11109-013-9228-2.

Stonecash, J.M. (2008). Reassessing the Incumbency Effect. Cambridge: Cambridge University Press.

Taylor, Z., McEleney, S. (2015). The Advantages of Incumbency and the Determinants of Municipal Candidate Vote Share: The 2014 City of Toronto Election. Pobrane z: https://www.assocsrv.ca/cpsa-acsp/2015event/Taylor-McEleney.pdf.

Titiunik, R. (2011). Incumbency Advantage in Brazil: Evidence from Municipal Mayor Elections. Pobrane z: http://www-personal.umich.edu/ titiunik/papers/Titiunik_IABrazil.pdf.

Trounstine, J. (2011). Evidence of a Local Incumbency Advantage. Legislative Studies Quarterly, 36(2), s. 255-280. DOI: 10.1111/j.1939-9162.2011.00013.x.

Trounstine, J. (2016). Information, Turnout and Incumbency in Local Elections. Pobrane z: https://www.princeton.edu/csdp/events/Trounstine020509/Trounstine020509. pdf.

Uppal, Y. (2009). The Disadvantaged Incumbents: Estimating Incumbency Effects in Indian State Legislatures. Public Choice, 138(1-2), s. 9-27. DOI: 10.1007/ s11127-008-9336-4.

Veiga, G.L., Veiga, F.J. (2007). Political Business Cycles at the Municipal Level. Public Choice, 131(1-2), s. 45-64. DOI: 10.1007/s11127-006-9104-2. 